\title{
Roseibium denhamense gen. nov., sp. nov. and Roseibium hamelinense sp. nov., aerobic bacteriochlorophyll-containing bacteria isolated from the east and west coasts of Australia
}

\author{
Tomonori Suzuki, Yasutaka Muroga, Manabu Takahama \\ and Yukimasa Nishimura
}

Department of Applied Biological Science, Science University of Tokyo, 2641, Yamazaki, Noda,

Chiba 278-8510, Japan Author for correspondence: Tomonori Suzuki. Tel: +8147124 1501. Fax: +81471239767.
e-mail: chijun@rs.noda.sut.ac.jp

Phenotypic and phylogenetic studies were performed with 10 strains of bacteriochlorophyll-containing bacteria isolated from a variety of marine environments (surface of Rhodophyta, sand and algal sand mat) on the east and west coasts of Australia. The strains were aerobic, chemoheterotrophic, Gram-negative, motile rods with peritrichous flagella. Bacteriochlorophyll a was synthesized under aerobic conditions. Catalase, nitrate reductase, oxidase and phosphatase were produced. ONPG reaction was positive. The strains have been divided into genotype group 1 (seven strains) and genotype group 2 (three strains) according to previously described DNA-DNA hybridization data. Strains OCh $254^{\top}$ and $0 \mathrm{Ch} 368^{\top}$ have been included in genotype groups 1 and 2 , respectively. The results of 165 rRNA gene sequence comparisons revealed that strains OCh $254^{\top}$ and $\mathrm{OCh} 368^{\top}$ formed a new cluster within the $\alpha-2$ group of the $\alpha$ subclass of the Proteobacteria. The similarity value of the 16S rRNA gene sequences between strain $0 \mathrm{Ch} 254^{\top}$ and the most closely related species, Stappia aggregata, was $\mathbf{9 5 . 6} \%$. The sequence similarity value between strains OCh $254^{\top}$ and $O C h \quad 368^{\top}$ was $97 \cdot 1 \%$. It was concluded that these two strains should be placed into a new genus, Roseibium gen. nov., as Roseibium denhamense sp. nov. and Roseibium hamelinense sp. nov. The type species of the genus is Roseibium denhamense. The type strains of Roseibium denhamense and Roseibium hamelinense are OCh 254 (= JCM 10543') and OCh $368^{\mathrm{T}}$ ( = JCM 10544'), respectively.

Keywords: Roseibium denhamense, Roseibium hamelinense, aerobic bacteriochlorophyll-containing bacteria, 16S rRNA

\section{INTRODUCTION}

Phototrophic bacteria generally synthesize bacteriochlorophylls under anaerobic conditions. However, Sato (1978) reported on aerobic methylotrophs containing bacteriochlorophyll $a$. To date, a lot of aerobic anoxygenic phototrophic bacteria have been described (Yurkov \& Beatty, 1998).

Aerobic and chemoheterotrophic bacteriochlorophyll-

The GenBank accession numbers for the 16S rRNA gene sequences of strains OCh $254^{\top}$ and OCh $368^{\top}$ are D85832 and D85836, respectively. containing bacteria have been isolated from a variety of marine environments (surface of Rhodophyta, sand and algal sand mat) on the east and west coasts of Australia (Shiba et al., 1991). These isolates have been divided into four phenotype groups (Group I-IV) based on colony colour, bacteriochlorophyll absorption spectrum and cell morphology. Each phenotype group (except Group III) has been divided into several genotype groups according to DNA-DNA hybridization data (Nishimura et al., 1994). Based on phenotypic characteristics and the phylogenetic considerations, we have recently proposed two new genera, Rubrimonas and Roseivivax, for Group III strains and 
two strains that do not belong to any genotype groups in Group II, respectively (Suzuki et al., 1999a, b). The genus Rubrimonas consists of one species, Rubrimonas cliftonensis, which is a short rod with polar flagella. Roseivivax possesses two species, Roseivivax halodurans and Roseivivax halotolerans, which are rods with subpolar flagella and can grow in up to $20.0 \%$ $(\mathrm{w} / \mathrm{v}) \mathrm{NaCl}$. These two genera belong to the $\alpha-3$ subclass of the Proteobacteria.

In the present study, the phenotypic characteristics of strains OCh $254^{\mathrm{T}}, 281,282,326,374,375$ and 445 of genotype group 1 and strains OCh $368^{\mathrm{T}}, 334$ and 355 of genotype group 2 in Group II were investigated and the $16 \mathrm{~S}$ rRNA genes of strains $\mathrm{OCh} 254^{\mathrm{T}}$ and $\mathrm{OCh}$ $368^{\mathrm{T}}$ were analysed. Based on the results of these investigations, a new genus, Roseibium gen. nov., with two new species, Roseibium denhamense sp. nov. and Roseibium hamelinense sp. nov., is proposed.

\section{METHODS}

Bacterial strains. Strains OCh $254^{\mathrm{T}}$, 281, 282, 326, 374, 375, $445,368^{\mathrm{T}}, 334$ and 355 were previously isolated from specimens from a variety of marine environments on the east and west coasts of Australia by Shiba et al. (1991). Strains OCh $254^{\mathrm{T}}$ and OCh 326 were isolated from Botryocladia sp. at Denham, Shark Bay. Strain OCh 281 was isolated from Botryocladia sp. at Little Lagoon, Shark Bay. Strains OCh 374 and OCh 375 were isolated from Laurencia sp. at Little Lagoon, Shark Bay. Strain OCh 282 was isolated from sands at Monkey Mia, Shark Bay. Strains OCh $368^{\mathrm{T}}$ and OCh 355 were isolated from sands at Hamelin Pool, Shark Bay. Strain OCh 334 was isolated from Botryocladia sp. at Shell Beach, Shark Bay. Strain OCh 445 was isolated from an algal sand mat at Arcadia, Magnetic Island. The strains were cultivated on PPES-II medium (Taga, 1968). The $\mathrm{pH}$ was adjusted to $7 \cdot 8$ with $10 \% \mathrm{NaOH}$.

Electron microscopy. Cells of strains OCh $254^{\mathrm{T}}$ and $\mathrm{OCh}$ $368^{\mathrm{T}}$ were stained with $1 \%(\mathrm{w} / \mathrm{v})$ aqueous uranyl acetate and examined under a JEOL model JEM-1200 EX electron microscope at an accelerating voltage of $80 \mathrm{kV}$.

Physiological and biochemical characteristics. Physiological and biochemical characteristics were examined according to the methods of Shiba \& Simidu (1982).

Preparation of chromosomal DNA. Strains OCh $254^{\mathrm{T}}$ and OCh $368^{\mathrm{T}}$ were grown in PPES-II broth at $27^{\circ} \mathrm{C}$ with shaking. The cells were resuspended in $0 \cdot 1 \mathrm{M}$ saline/EDTA $(0.15 \mathrm{M} \mathrm{NaCl}, 0.1 \mathrm{M}$ EDTA, $\mathrm{pH} 8.5)$ and then lysed at $60{ }^{\circ} \mathrm{C}$ for $10 \mathrm{~min}$ with $0.5 \% \mathrm{SDS}$ (final concentration). Chromosomal DNA was purified according to standard procedures (Sambrook et al., 1989).

Amplification of the 16S rRNA gene and sequence analysis. Amplification of the 16S rRNA gene was performed on a Quick Thermo Personal QTP-1 (Nippon Genetics) in $100 \mu \mathrm{l}$ reaction volume as described previously (Suzuki et al., 1999a, b). The amplified DNA fragments were purified by gel electrophoresis on $1 \%(\mathrm{w} / \mathrm{v})$ Agarose $\mathrm{S}$ (Nippon Gene) and recovered with glass powder using Prep-A-Gene DNA Purification Systems (Bio-Rad). Sequencing was carried out according to the previous paper (Suzuki \& Yamasato, 1994).

Phylogenetic analysis. The determined sequence and the sequences of reference bacterial species were aligned with the program CLUSTAL $\mathrm{x}$ version $1 \cdot 64 \mathrm{~b}$ (Thompson et al., 1997). The alignment was checked manually. Phylogenetic analysis was performed with PHYLIP version 3.57c (Felsenstein, 1995). A distance matrix was calculated with DNADIST using the Kimura two-parameter correction and a phylogenetic tree was reconstructed using NEIGHBOR. The stability of the clusters was ascertained by performing a bootstrap analysis (1000 replications) with DNABOOT, DNADIST, NEIGHBOR and CONSENSE.

\section{RESULTS}

\section{Colony and cell morphology}

Colonies of all the strains were circular, smooth, slightly convex, entire, glistening, opaque and pink. Electron micrographs of negatively stained cells (OCh $254^{\mathrm{T}}$ and OCh $368^{\mathrm{T}}$ ) showed that they were rods with peritrichous flagella (Fig. 1). Cells of strains OCh $254^{\mathrm{T}}$, $281,326,374,375,445,368^{\mathrm{T}}, 334$ and 355 were $0.5-0.8 \times 1.0-4.0 \mu \mathrm{m}$ and cells of strain OCh 282 were $0.5 \times 3 \cdot 0-6 \cdot 0 \mu \mathrm{m}$.

\section{Physiological and biochemical characteristics}

All strains grew chemoheterotrophically under aerobic conditions, but could not grow phototrophically under anaerobic conditions in the light. They synthesized bacteriochlorophyll $a$ under aerobic conditions. Optimum growth occurred at $\mathrm{pH} 7 \cdot 5-8.0$ and at $27-30{ }^{\circ} \mathrm{C}$. Some of the physiological and biochemical properties of strains OCh $254^{\mathrm{T}}$ and OCh $368^{\mathrm{T}}$ are shown in Table 1. All strains were positive for catalase, nitrate reductase, oxidase and phosphatase activity. VogesProskauer test was negative. ONPG reaction was positive. The strains produced indole, but not $\mathrm{H}_{2} \mathrm{~S}$. They hydrolysed gelatin, but not alginate, starch or Tween 80. All strains utilized butyrate, L-glutamate, pyruvate and L-aspartate, but did not utilize glycolate, ethanol and methanol. Acids were produced from Dfructose, D-glucose, D-ribose and maltose, but were not produced from L-arabinose or lactose. They were resistant to penicillin and tetracycline, but were sensitive to chloramphenicol and streptomycin.

Genotype group 1 strains possessed urease activity. The strains hydrolysed gelatin (except OCh 445), but did not hydrolyse Tween 80 . They utilized D-glucose (except OCh 281), acetate, citrate (except OCh 282, 326 and 445), fumarate, glycolate (except OCh 254, 281 and 282), DL-lactate (except OCh 254, 281 and 282), DL-malate (except OCh 282), pyruvate (except OCh 281), succinate (except OCh 282 and OCh 326) and L-aspartate (except OCh 281 and OCh 282). Acids were produced from D-galactose, D-xylose, maltose (except OCh 281 and OCh 326) and sucrose. All genotype group 1 strains required $\mathrm{NaCl}$ for growth and could grow in $0.5-7 \cdot 5 \% \mathrm{NaCl}$ (strain OCh $254^{\mathrm{T}}$ could grow up to $10 \cdot 0 \% \mathrm{NaCl}$ ).

Genotype group 2 strains also possessed urease activity (except OCh $368^{\mathrm{T}}$ ). The strains hydrolysed gelatin and Tween 80 (except OCh $368^{\mathrm{T}}$ ). They utilized D-glucose, 

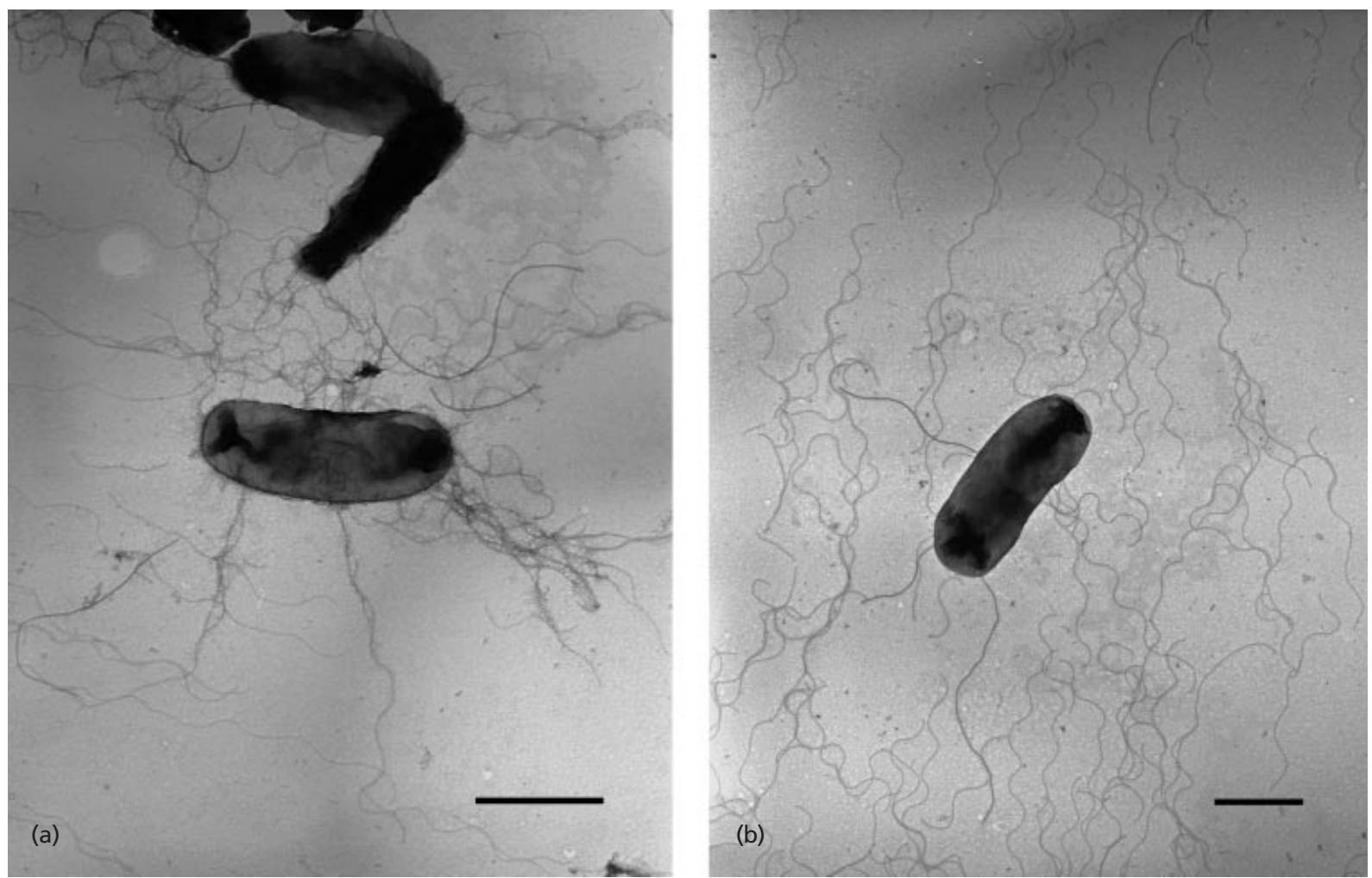

Fig. 1. Electron micrographs of negatively stained cells of strains $O C h 254^{\top}$ (a) and $O C h 368^{\top}$ (b). Bars, $1 \mu \mathrm{m}$.

Table 1. Physiological and biochemical characteristics of Roseibium denhamense OCh $254^{\top}$ and Roseibium hamelinense OCh $368^{\top}$

+ , Positive; - , negative; w, weakly positive.

\begin{tabular}{|lcc|}
\hline Character & OCh $254^{\mathrm{T}}$ & OCh $^{\mathbf{3 6 8}} \mathbf{P}^{\mathrm{T}}$ \\
\hline Urease & + & - \\
Utilization of: & & \\
D-Glucose & $\mathrm{W}$ & + \\
Acetate & + & - \\
Citrate & $\mathrm{W}$ & - \\
Fumarate & + & - \\
DL-Lactate & - & + \\
DL-Malate & + & - \\
Succinate & $\mathrm{W}$ & - \\
Acid production from: & & - \\
D-Galactose & + & - \\
D-Xylose & + & $\mathrm{W}$ \\
Sucrose & + & + \\
Growth in the presence & - & \\
of $0 \%$ NaCl & & \\
\hline
\end{tabular}

DL-lactate, pyruvate, succinate (except OCh $368^{\mathrm{T}}$ ) and L-aspartate, but did not utilize acetate (except $\mathrm{OCh}$ 334), citrate, fumarate (except OCh 334), glycolate or
DL-malate (except OCh 355). Acids were produced from maltose and sucrose (except OCh 334), but were not produced from D-galactose or D-xylose. The strains could grow in $0-10 \cdot 0 \% \mathrm{NaCl}$.

\section{Phylogenetic analysis}

The 16S rRNA gene sequences of strains $\mathrm{OCh} 254^{\mathrm{T}}$ and $\mathrm{OCh} 368^{\mathrm{T}}$ were determined and aligned with the other available $16 \mathrm{~S}$ rRNA gene sequences of strains belonging to the $\alpha$ subclass of the Proteobacteria. A comparison of the $16 \mathrm{~S}$ rRNA gene sequences in which a phylogenetic tree was reconstructed (Fig. 2) revealed that strains OCh $254^{\mathrm{T}}$ and $\mathrm{OCh} 368^{\mathrm{T}}$ belonged to the $\alpha-2$ subclass of the Proteobacteria. The $16 \mathrm{~S}$ rRNA gene sequence similarity values of strain OCh $254^{\mathrm{T}}$ to Stappia aggregata and Stappia stellulata were 95.6 and $92.0 \%$, respectively. The $16 \mathrm{~S}$ rRNA gene sequence similarity values of strain $\mathrm{OCh} 368^{\mathrm{T}}$ to $S$. aggregata and $S$. stellulata were 96.7 and $93.4 \%$, respectively. The similarity value of the $16 \mathrm{~S}$ rRNA gene sequences between strains $\mathrm{OCh} 254^{\mathrm{T}}$ and $\mathrm{OCh} 368^{\mathrm{T}}$ was $97 \cdot 1 \%$.

\section{DISCUSSION}

Shiba et al. (1991) isolated aerobic and chemoheterotrophic bacteriochlorophyll-containing bacteria from specimens from a variety of marine environments on the east and west coasts of Australia. Nishimura et al. 


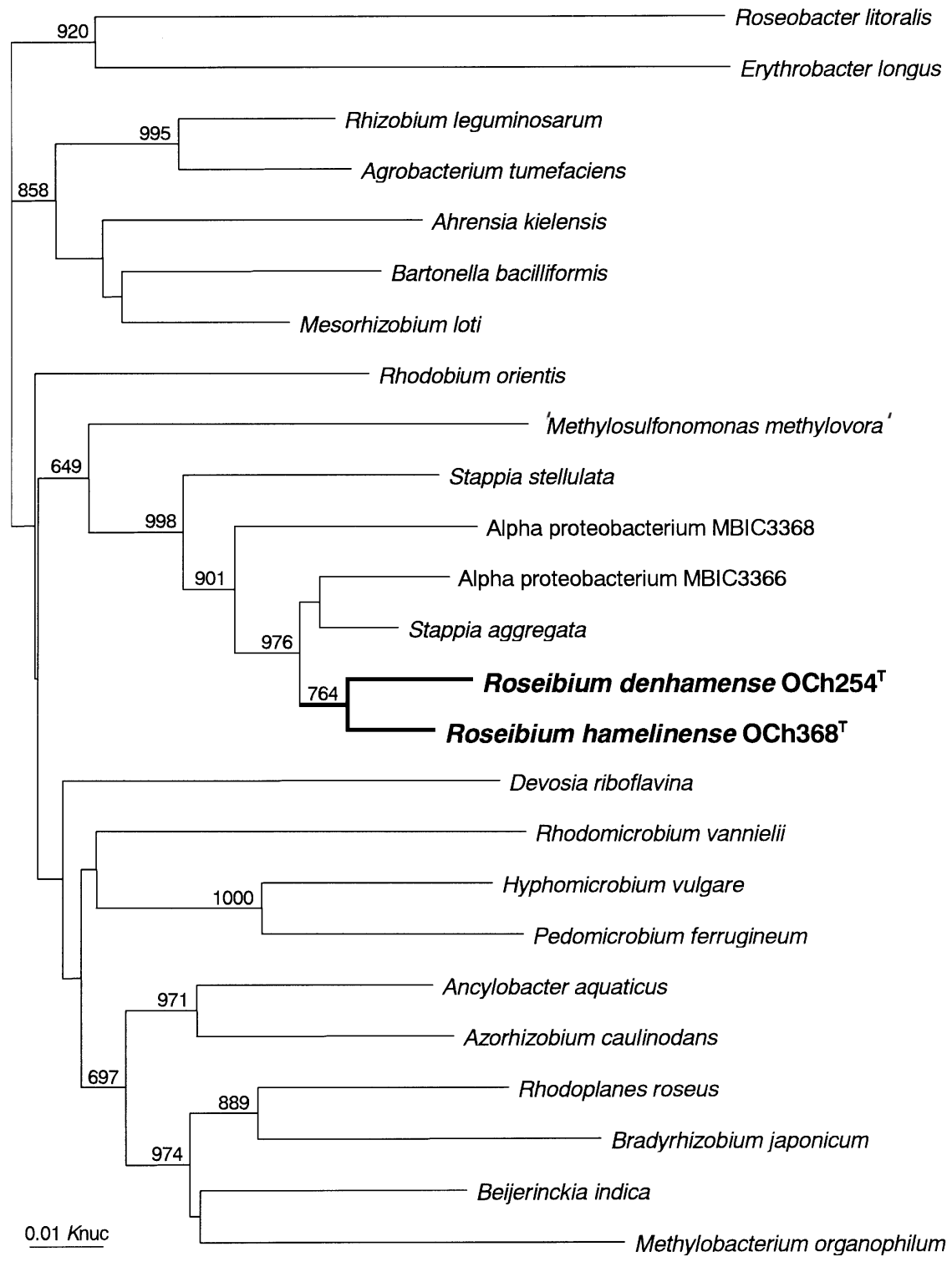

Fig. 2. Unrooted phylogenetic tree derived from the analysis of the $16 \mathrm{~S}$ rRNA gene sequences of Roseibium denhamense OCh $254^{\top}$, Roseibium hamelinense OCh $368^{\top}$ and other members of the $\alpha$ subclass of the Proteobacteria. The numbers at the nodes indicate the levels of bootstrap support based on 1000 resamplings. Only significant values (above 600) are indicated.

(1994) divided these isolates into four groups (I-IV) on the basis of colony colour, bacteriochlorophyll absorption spectrum and cell morphology. Strains of Group II have been divided into four genotype groups according to DNA-DNA hybridization data. Strains OCh $254^{\mathrm{T}}$ and $\mathrm{OCh} 368^{\mathrm{T}}$ have been included into genotype groups 1 and 2 , respectively.

To date, the taxonomic positions of these genotype groups has not been clear. To solve this problem, a phylogenetic analysis based on 16S rRNA gene sequences was carried out. In consequence, it was revealed that strains OCh $254^{\mathrm{T}}$ and OCh $368^{\mathrm{T}}$ formed a new cluster within the $\alpha-2$ subclass of the Proteobacteria.
The sequence similarity values of the cluster to the related organisms Stappia aggregata and Stappia stellulata were $92 \cdot 0-96 \cdot 7 \%$. The genus Stappia was proposed by Uchino et al. (1998) to accommodate two marine 'Agrobacterium' species. The phylogenetic analysis supports the creation of a new genus, Roseibium, for strains of genotype groups 1 and 2 in Group II.

The 16S rRNA gene sequence similarity value between strains OCh $254^{\mathrm{T}}$ and OCh $368^{\mathrm{T}}$ was $97 \cdot 1 \%$. The chromosomal DNA homology values between these strains were $12-17 \%$ and the DNA homology values between strains of genotype groups 1 and 2 were 
$75-100 \%$ and $98-99 \%$, respectively (Nishimura et al., 1994). These results indicate that the strains of genotype groups 1 and 2 are different species.

In conclusion, we propose that strains OCh $254^{\mathrm{T}}, 281$, $282,326,374,375$ and 445 of genotype group 1 should be described as Roseibium denhamense gen. nov., sp. nov., and strains OCh $368^{\mathrm{T}}, 334$ and 355 of genotype group 2 as Roseibium hamelinense sp. nov.

\section{Description of Roseibium gen. nov.}

Roseibium (ro.sei'bi.um. M. L. adj. roseus rose/pink; Gr. n. bios life; M. L. neut. n. Roseibium pink life).

Cells are Gram-negative rods that are motile by means of peritrichous flagella. Growth is aerobic and chemoheterotrophic. Bacteriochlorophyll $a$ is synthesized under aerobic conditions. Cultures do not grow anaerobically in the light. Catalase, nitrate reductase, oxidase and phosphatase are produced. The ubiquinone system is Q-10 and the major cellular fatty acid is C18: 1 (Nishimura et al., 1994). The genus Roseibium belongs to the $\alpha-2$ subclass of the Proteobacteria. The type species is Roseibium denhamense.

\section{Description of Roseibium denhamense sp. nov.}

Roseibium denhamense (den.ha.men'se. M. L. adj. denhamense referring to Denham, Australia, the source of the type strain).

Colonies are circular, smooth, slightly convex, entire, glistening, opaque and pink. Cells are 0.5-0.8 $\times$ $1 \cdot 0-4.0 \mu \mathrm{m}$, except strain OCh 282 which is $0.5 \times$ $3 \cdot 0-6 \cdot 0 \mu \mathrm{m}$. Voges-Proskauer test is negative. ONPG reaction is positive. Cells produce indole, but do not produce $\mathrm{H}_{2} \mathrm{~S}$. Alginate, starch and Tween 80 are not hydrolysed. Cells utilize acetate, butyrate, fumarate and L-glutamate, but do not utilize ethanol or methanol. Acids are produced from D-fructose, D-galactose, D-glucose, D-ribose, D-xylose and sucrose, but are not produced from L-arabinose or lactose. Cells are resistant to penicillin and tetracycline, but are sensitive to chloramphenicol and streptomycin. Optimum growth occurs at $\mathrm{pH} 7 \cdot 5-8.0$ and at $27-30^{\circ} \mathrm{C}$. Growth occurs in the presence of $0.5-7 \cdot 5 \%(\mathrm{w} / \mathrm{v}) \mathrm{NaCl}$, except strain OCh $254^{\mathrm{T}}$ which can grow in the presence of $0.5-10.0 \%(\mathrm{w} / \mathrm{v}) \mathrm{NaCl}$. No growth occurs in the absence of $\mathrm{NaCl}$. The absorption spectrum of the membrane fraction in the near-IR region has maxima at 803-805 and 863-864 nm (Nishimura et al., 1994). The DNA G + C content is $57 \cdot 6-60 \cdot 4 \mathrm{~mol} \%$ (Nishimura et al., 1994). The type strain is OCh $254^{\mathrm{T}}$ (= JCM $10543^{\mathrm{T}}$ ), which was isolated from Botryocladia sp. at Denham, Shark Bay, Australia.

\section{Description of Roseibium hamelinense sp. nov.}

Roseibium hamelinense (ha.me.li.nen'se. M. L. adj. hamelinense referring to Hamelin Pool, Australia, the source of the type strain).
Colonies are circular, smooth, slightly convex, entire, glistening, opaque and pink. Cells are 0.5-0.8 $\times$ $1 \cdot 0-4.0 \mu \mathrm{m}$. Voges-Proskauer test is negative. ONPG reaction is positive. Cells produce indole, but do not produce $\mathrm{H}_{2} \mathrm{~S}$. Gelatin is hydrolysed, but alginate and starch are not. Cells utilize D-glucose, butyrate, DLlactate, pyruvate, L-aspartate and L-glutamate, but do not utilize citrate, glycolate, ethanol or methanol. Acids are produced from D-fructose, D-glucose, Dribose and maltose, but are not produced from Larabinose, D-galactose, D-xylose or lactose. Cells are resistant to penicillin and tetracycline, but are sensitive to chloramphenicol and streptomycin. Optimum growth occurs at $\mathrm{pH} 7 \cdot 5-8.0$ and at $27-30{ }^{\circ} \mathrm{C}$. Growth occurs in the presence of $0-10.0 \%(\mathrm{w} / \mathrm{v}) \mathrm{NaCl}$. The absorption spectrum of the membrane fraction in the near-IR region has maxima at 803-805 and 872$873 \mathrm{~nm}$ (Nishimura et al., 1994). The DNA G+C content is $59 \cdot 2-63.4 \mathrm{~mol} \%$ (Nishimura et al., 1994). The type strain is OCh $368^{\mathrm{T}}\left(=\mathrm{JCM} 10544^{\mathrm{T}}\right)$, which was isolated from sands at Hamelin Pool, Shark Bay, Australia.

\section{ACKNOWLEDGEMENTS}

We are grateful to Dr Tsuneo Shiba (National Fisheries University, Shimonoseki, Japan) for providing bacterial strains. We also thank Isamu Mutoh (Department of Applied Biological Science, Science University of Tokyo, Noda, Japan) for his help with electron microscopy.

\section{REFERENCES}

Felsenstein, J. (1995). PHYLIP (phylogeny inference package), version 3.57c. Seattle: University of Washington.

Nishimura, Y., Muroga, Y., Saito, S., Shiba, T., Takamiya, K. \& Shioi, Y. (1994). DNA relatedness and chemotaxonomic feature of aerobic bacteriochlorophyll-containing bacteria isolated from coasts of Australia, J Gen Appl Microbiol 40, 287-296.

Sambrook, J., Fritsch, E. F. Maniatis, T. (1989). Molecular Cloning : a Laboratory Manual, 2nd edn. Cold Spring Harbor, NY : Cold Spring Harbor Laboratory.

Sato, K. (1978). Bacteriochlorophyll formation by facultative methylotrophs, Protaminobacter ruber and Pseudomonas AM1, FEBS Lett 85, 207-210.

Shiba, T. \& Simidu, U. (1982). Erythrobacter longus gen. nov., sp. nov., an aerobic bacterium which contains bacteriochlorophyll a, Int J Syst Bacteriol 32, 211-217.

Shiba, T., Shioi, Y., Takamiya, K., Sutton, D. C. \& Wilkinson, C. R. (1991). Distribution and physiology of aerobic bacteria containing bacteriochlorophyll $a$ on the east and west coasts of Australia, Appl Environ Microbiol 57, 295-300.

Suzuki, T. \& Yamasato, K. (1994). Phylogeny of spore-forming lactic acid bacteria based on $16 \mathrm{~S}$ rRNA gene sequences, FEMS Microbiol Lett 115, 13-18.

Suzuki, T., Muroga, Y., Takahama, M., Shiba, T. \& Nishimura, Y. (1999a). Rubrimonas cliftonensis gen. nov., sp. nov., an aerobic bacteriochlorophyll-containing bacterium isolated from saline lake, Int J Syst Bacteriol 49, 201-205.

Suzuki, T., Muroga, Y., Takahama, M. \& Nishimura, Y. (1999b). Roseivivax halodurans gen. nov., sp. nov. and Roseivivax halotolerans sp. nov., aerobic bacteriochlorophyll-containing 
bacteria isolated from a saline lake, Int J Syst Bacteriol 49, 629-634.

Taga, N. (1968). Some ecological aspects of marine bacteria in the kuroshio current, Bull Misaki Mar Biol Inst Kyoto Univ 12, 56-76.

Thompson, J. D., Gibson, T. J., Plewniak, F., Jeanmougin, F. \& Higgins, D. G. (1997). The CLUSTAL X windows interface: flexible strategies for multiple sequence alignment aided by quality analysis tools, Nucleic Acids Res 24, 4876-4882.
Uchino, Y., Hirata, A., Yokota, A. \& Sugiyama, J. (1998). Reclassification of marine Agrobacterium species: proposals of Stappia stellulata gen. nov., comb. nov., Stappia aggregata sp. nov., nom. rev., Ruegeria atlantica gen. nov., comb. nov., Ruegeria gelatinovora comb. nov., Ruegeria algicola comb. nov., and Ahrensia kieliense gen. nov., sp. nov., nom. rev, J Gen Appl Microbiol 44, 201-210.

Yurkov, V. \& Beatty, J. T. (1998). Aerobic anoxygenic phototrophic bacteria, Microbiol Mol Biol Rev 62, 695-724. 